ISSN 0258-7122

Bangladesh J. Agril. Res. 33(3) : 565-570, December 2008

\title{
CONTRIBUTION OF BARI CEREAL CROPS TO THE NATIONAL GDP OF BANGLADESH
}

\author{
M. R. KARIM ${ }^{1}$, MA. BASET ${ }^{2}$, Q. M. ALAM ${ }^{3}$, S. HOSSAIN $^{4}$
}

\begin{abstract}
The study was conducted to estimate the contribution made by BARI cereal crops to GDP in the national economy of Bangladesh during the financial year 2005-2006. For the purpose of GDP calculation of BARI cereal crops, both primary and secondary data were collected from the concerned scientists of BARI, BBS, and DAM. Bangladesh has produced total goods and services those valuation at constant market price of Tk. 3150370.14 million in the financial year 2005-2006, where the contribution of agriculture and forestry was found Tk. 467436.18 million. Primarily producers sell their crops to the different users at farm-gate price and then the final output flour, bread, biscuit, poultry feed and its by-product straw, cattle feed, fuel and fodder for further value added when it is marketed to the consumer via a number of intermediaries. The value added price of the goods and services of BARI cereal crops were found at constant market price of Tk. 31434.75 million that comes as GDP valuation to the national economy. Finally, the contribution of BARI cereal crops to the agricultural and forestry GDP as worked out at 6.72 percent. On the other hand, contribution to GDP of BARI cereal crop technologies was found to be 4.40 percent.
\end{abstract}

Key Words: Contribution, BARI cereal, national GDP.

\section{Introduction}

Wheat, maize, barley and millets are the mandatory cereal crops of Bangladesh Agricultural Research Institute (BARI). All the four cereal crops were cultivated in 0.63 million hectares and produced 1.5 million tons of grain. In percentage, it occupies about 6.09 percent area and produced about 5.58 percent of total cereals (BBS, 2006). All the BARI cereal crops have the diversified uses for making flour, bread, biscuit, pizza, cream role, poultry feed, cattle feed, stretch, etc. And their byproduct can be used as fuel in the rural areas of Bangladesh to a remarkable extent. The demand for both consumption as food and fuel were found increasing tremendously day by day. It becomes impossible to meet the growing demand of cereal from domestic production. That is why government has to import the cereals from abroad by spending our valuable foreign exchange. In this regard, priority must he given for the development of BARI mandatory cereal crops very soon. In the year 2005-06, 462.72 thousand metric tons flour, 71.19 thousand metric tons

${ }^{1}$ Senior Scientific Officer, ${ }^{2 \& 3}$ Principal Scientific Officer, Agricultural Economics Division, BARI, Joydebpur, Gazipur, ${ }^{4}$ Senior Scientific Officer, T\&C Wing, BARI, Joydebpur, Bangladesh. 
bread, 149.49 thousand metric ton biscuit and 28.48 thousand metric tons other products were produced from wheat, while 749.75 thousand metric tons feed and 31.24 thousand metric tons other products were produced from maize. On the other land, in total 10.66 thousand metric tons of other products produced from barley and millets, respectively. In addition, 1.54 million tons of straw and 0.04 million tons of cattle feed were produced from wheat, while 0.55 million tons of fodder and 0.27 million tons of fuel were produced from maize.

So, it is important to note that the increase in production of BARI cereal crops is not only to meet up country's growing demand but also increase national Gross Domestic Product (GDP). Besides, these cereal crops plays an important role in developing rural infrastructure, employment, income of the farm families, contribution to national exchequer, foreign exchange saving aid value addition. though these cereal crops play a vital role in the economy but the contribution of individual crop was not shown separately in national economy and it is somehow included in agricultural sector as a whole and it is necessary to quantity the contribution of BARI cereal crops to GDP. Earlier, World Bank ARMP consultant (Nagy and Alam, 2000) conducted an ex-post rate of return analysis to estimate the internal rate of return (IRR) and foreign exchange savings to BARI released all of wheat research and extension investment in Bangladesh. The IRR to the total insestment in both wheat research and extension was calculated at 32 percent along with the foreign echangc savings of Tk. 7.9 billion, which can be considered as an acceptable rate of return to wheat research and extension investment. The study was undertaken with a view to finding out the BARI cereal crops contribution to GDP in the national economy.

\section{Objectives}

The objectives were a) to determine the area and production of BARI cereal crops, b) to quantity the contribution made by BARI cereal crops to the agriculture and forestry (GDP) and e) to formulate a policy guideline for scientists, extension personnel, planners, and policy makers.

\section{Methodology}

Generally, Gross Domestic Product (GDP) means total valuation of goods and services produced annually in a country. There are two sides for GDP calculation. The income side of the accounts measures the factor incomes that earned by workers in produced goods and services in the economy. On the product side, the flow of goods and services currently produced by workers is measured by expenditures of these goods and services by consumers, business and government (Branson, 1979).

For estimating the contribution of BARI cereal crops to GDP needs first to quantify the percentage amount of BARI cereal crops used for various value added 
Produets based on Household Income and Expenditure Survey, 2000, BARI Annual Reports of 2003-04 and 2004-05. Accordingly, the wheat used as seed amounted to 8 percent of total production and thereafter the rest was used for produceing flour, bread, biscuit and others amounted to 65,10,21 and 4 percent, respectively. In addition, 8 percent wheat bran was found in the process of making flour from sheat. The wheat straw as calculated by multiplying twice the total grain production. While the total maize grain used for producing 96 percent of feed and the rest used as other products. The fodder and fuel from maize were calculated considering $4 \mathrm{t} / \mathrm{ha}$ and $2 \mathrm{t} / \mathrm{ha}$, respectively. On the other, after keeping the seed hundred percent of minor cereals barley and millet used only for producing other products (BARI Annual Reports, 2003-04 and 2004-05). After that, we accounted the farmgate price of total production, value added prices of seed. flour, bread, biscuit, others, maize feed, maize fodder, maize fuel, wheat straw and wheat bran. It contributes to the rural farm employment as sell as countries national economy.

The present study was carried out considering the cropping year 2005-2006. For calculating GDP of BARI cereal, secondary data were collected from BBS Pocket Book, 2005. Krishi Diary, 2007, Bangladesh Economic Review, 2006, Hand Book of Agricultural Technology, 1999. l'he year 1999-2000 was considered as base year and GDP sas calculated at constant market price for the period 2005-2006. Bangladesh has produced total goods and services valuation at constant market price of Tk. 3150370.14 million in the financial year 2005-06 where the contribution of agriculture and forestry was at 14.84 percent (467436.18 million) (Economic Review, 2006).

\section{Results and Discussion}

\section{Area and prodnction}

Table 1 represents total area and production of BARI cereal crops and total rice crops. BARI cereal crops cover 631200 hectare of land area and produced 1566900 tons cereals. In percentage, BARI cereal crops' area covered only 608 percent and produced 5.58 percent production of total rice area and production, respectively.

Table 1. Total area and production of BARI cereals (2005-06).

\begin{tabular}{|c|c|c|}
\hline \multirow{2}{*}{ Cereals } & Area & Production \\
\hline & Hectare & Ton \\
\hline Wheat & 481000.00 & 772000.00 \\
\hline Maize & 137000.00 & 784000.00 \\
\hline Barly & 1200.00 & 1000.00 \\
\hline Millet & 12000.00 & 9900.00 \\
\hline BARI cereals total & 631200.00 & 1566900.00 \\
\hline Total rice & 10372874.49 & 28076000.00 \\
\hline$\%$ of total rice & 60.09 & 5. 58 \\
\hline
\end{tabular}

Source: BBS 2005 


\section{Value addition items, prices and their share}

Table 2 shows that several items were produced from wheat, such as grain, bread, biscuit, flour, etc. Maize was used as a grain and poultry feed. Whereas, barley and millet were used as grain. It is evident from the Table that the highest straw was obtained from wheat of 1544.00 thousand tons, while the lowest 37.02 thousand tons of wheat was used as cattle feed. On the other hand, highest value addition was obtained from poultry feed worth Tk. 11351.44 million followed by biscuit Tk. 8473.00, flour Tk. 6216.47, bread Tk. 1972.38, others Tk. 1664.84, wheat straw Tk. 701.30. cattle feed Tk. 420.34, fadder Tk. 414.85. fuel Tk. 103.71 and seed Tk. 116.42 million (Table 3). Table 4 represents the value addition prices of different items produced from BARI cereal crops.

Table 2. Production of different items produced from BARI cereals (000 ton).

\begin{tabular}{lllll|l|l}
\hline \multicolumn{1}{c|}{ Items } & \multicolumn{1}{c}{ Wheat } & \multicolumn{1}{c}{ Maize } & \multicolumn{1}{c}{ Barley } & \multicolumn{1}{c}{ Millets } & \multicolumn{1}{c}{ Total } \\
\hline Grain & 772.00 & 784.00 & 1.00 & 9.90 & 1566.90 \\
Seed & 60.13 & 3.01 & 0.01 & 0.23 & 63.38 \\
Flour & 462.72 & - & - & - & 462.72 \\
Bread & 71.19 & - & - & - & 71.19 \\
Biscuit & 149.49 & - & - & - & 149.49 \\
Others & 28.48 & 31.24 & 0.99 & 9.67 & 70.37 \\
Maize Feed & - & 749.75 & - & - & 749.75 \\
Maize Fodder & - & 584.00 & - & - & 584.00 \\
Maize Fuel & - & 274.00 & - & - & 274.00 \\
Wheat Straw & 1544.00 & - & - & - & 1544.00 \\
Wheat Bran & 37.02 & - & - & - & 37.02 \\
\hline
\end{tabular}

Source: Auihors'own estimation

Table 3. Value added (Million Tk.) of different items produced from BARI cereals (at constant price 1999-00).

\begin{tabular}{l|l|l|l|l|l}
\hline \multicolumn{1}{c|}{ Items } & \multicolumn{1}{c}{ Wheat } & \multicolumn{1}{c}{ Maize } & \multicolumn{1}{c}{ Barley } & \multicolumn{1}{c}{ Millets } & \multicolumn{1}{c}{ Total } \\
\hline Seed & 81.93 & 34.22 & 0.01 & 0.26 & 116.42 \\
Flour & 6216.47 & - & - & - & 6216.47 \\
Bread & 1972.38 & - & - & - & 1972.38 \\
Biscuit & 8473.00 & & & & 8473.00 \\
Others & 673.63 & 739.03 & 23.37 & 228.81 & 1664.84 \\
Maize feed & 11351.44 & & & & 11351.44 \\
Maize fodder & 414.85 & & & & 414.85 \\
Maize fuel & 103.71 & & & & 103.71 \\
Wheat straw & 701.30 & & & & 701.30 \\
Wheat bran & 420.34 & & & & 420.34 \\
& 18539.05 & 12643.25 & 23.38 & 229.07 & 31434.75 \\
\hline
\end{tabular}

Source: Authors'oswn estimation 
Table 4. Prices of different items obtained from BARI cereal crops (Tk/t).

\begin{tabular}{l|l|l|l|l}
\hline \multicolumn{1}{c}{ Items } & \multicolumn{1}{c}{ Wheat } & \multicolumn{1}{c}{ Maize } & \multicolumn{1}{c}{ Barley } & \multicolumn{1}{c}{ Millets } \\
\hline Grain & 17000.00 & 8000.00 & 7000.00 & 7000.00 \\
Seed & 18000.00 & 150000.00 & 11000.00 & 15000.00 \\
Flour & 19290.00 & - & - & - \\
Bread & 36600.00 & - & - & - \\
Biscuit & 74870.00 & - & - & - \\
Others & 31250.00 & - & 31250.00 & 31250.00 \\
Maize Feed & - & 20000.00 & - & - \\
Maize Fodder & - & 1000.00 & - & - \\
Maize Fuel & - & 500.00 & - & - \\
Wheat Straw & 600.00 & - & - & - \\
Wheat Bran & 15000.00 & - & - & - \\
\hline
\end{tabular}

Source: Monthly Statistical Bulletin-August 2006 and Field Survey

\section{Whole scenario of BARI cereal crops}

Table 5 represents the whole scenario of BARI cereal crops contribution to our national GDP. Total GDP of agriculture and forestry was Tk. 467436.18 million at constant price in 1900-2000 while BARI cereal crops contributed Tk. 31434.75 at constant price in 1900-2000. In percentage, BARI cereal crops contributed 6.72 percent of agriculture and forestry to the national GDP. When the adoption of BARI cereal crops technologies considererd then its percentage becomes 4.40 percent.

Table 5. GDP valuation (Million Tk) of BARI cereals in the financial year 2005-06 at constant price (Base Year 1999-00).

\begin{tabular}{|c|c|c|c|}
\hline Items & Indicators & Value & Value \\
\hline Total GDP in the year 2005-06 (Million Tk.) & 3150370.14 & addition & addition \\
\hline Ag. \& forestry in National GDP (Million T k.) & 467436.18 & (Million & (Million Tk.) \\
\hline Total BARI cereals Area (ha) & 631200.00 & Tk.) & from BARI \\
\hline Total BARI cereals production (ml) & I566900.00 & & techonologies \\
\hline Grain (000 mt) & 1566.90 & & \\
\hline Seed (000 mt) & 63.38 & 116.42 & 116.42 \\
\hline Flour (000 mt) & 462.72 & 6216.47 & 6216.47 \\
\hline Bread (000 ) & 71.19 & 197238 & 197238 \\
\hline Biscuit (000 mt) & 49.49 & 18473.00 & 8473.00 \\
\hline Others (000 mt) & 70.37 & 1664.84 & 1664.84 \\
\hline Maize feed $(000 \mathrm{ml})$ & 749.75 & 11351.44 & 1135.14 \\
\hline Maize Fodder (000 rnt) & 584.00 & 414.85 & 41.48 \\
\hline Maize Fuel (000 mt) & 274.00 & 103.71 & 10.37 \\
\hline Wheat Straw (000 mt) & 1544.00 & 701.30 & 701.30 \\
\hline Wheat Bran (000 mt) & 37.02 & 420.34 & 420.34 \\
\hline $\begin{array}{l}\text { Total contribution of BARI cereals in Ag. \& } \\
\text { forestr) to GDP }\end{array}$ & & 31434.75 & 20751.76 \\
\hline $\begin{array}{l}\text { Total contribution of BARI cereals to National } \\
\text { Ag. \& forestry to GDP }\end{array}$ & & $6.72 \%$ & $4.40 \%$ \\
\hline
\end{tabular}

Sources: BBS Pocket Book 2005. Krishi Diary 2007. Economic Review 2000 and Hand Book of Agricultural Technology, $3^{\text {rd }}$ edition, BARI, Gzzipur-1701, Bangladesh, 1999. 


\section{Policy implication}

The demand for both consumption as food and fuel were found increasing of all the BARI cereal crops to remarkable extent in both rural and urban areas of Bangladesh. All the BARI cereal crops have the diversified uses for making flour, bread, biscuit, pizza, cream role, poultry feed, cattle feed, stretch, etc. It has become impossible to meet the growing demand from our present cereal crop production. That is why government has to import the cereal crops from abroad by spending our valuable foreign exchange. In this regard, priority must he given for the development of BARI mandatory cereal crops very soon.

\section{References}

Agricultural Information Service (AIS). 2007. Krishi Diary. Ministry of Agriculture. Government of the People's Republic of Bangladesh.

Ahmed, S. M and C. A. Meisner. 1996. Wheat Research \& Development in Bangladesh.

Bangladesh Bureau of Statistics (BBS). 2005. Ministry of Planning. Gos ernment of the Peopl\&s Republic of Bangladesh.

Bangladesh Bureau of Statistics (BBS). 2005. Statistical Pocket Book. Ministry of Planning. Government of the People's Republic of Bangladesh.

Bangladesh Bureau of Statistics (BBS). 2000. I lousehold Income and Fxpenditure Sun cy. Ministry of Planning. Government of the People's Republic of Bangladesh.

Bangladesh Economic Review. 2006. Economic Adviser's Wing. Finance Division. Ministry of Finance. Government of the People’s Republic of Bangladesh. January' 2007.

BARI (Bangladesh Agricultural Research Institute) 1999. Hand Book of Agricultural Technology 3” edition, Joydebpur, Bangladesh.

BARI (Bangladesh Agricultural Research Institute). 2004. Annual Report (2003-04). BARI, Joydebpur, Bangladesh.

BARI (Bangladesh Agricultural Research Institute). 2005. Annual Report (2004-05). BARI, Joydebpur, Bangladesh.

Nagy, J. G. and M. F. Alam. 2000. The Impact of Agricultural Research in Bangladesh. A Consultancy Report, BARC, Farmgate, Dhaka. 